\title{
Constructivist-based English language teaching in middle vocational school
}

\author{
Wenyi Liu \\ English Teaching and Learning Group \\ Dalian Light Industry School \\ Dalian, China \\ 1020241462@qq.com
}

\begin{abstract}
In order to raise students' English language competences, the Constructivist-based teaching mode is applied in the English language teaching and learning process. The interactive and collaborative nature of Constructivist-based offers opportunities for language learning beyond traditional pedagogy. From the constructivist paradigm of teaching English, authentic experience is greatly emphasized as experiential learning enables students to appreciate English and a sure way of getting students interested in English learning. The investigation shows that English language competences can cultivate students' language skills, language knowledge, emotional attitudes, learning strategy and cultural awareness. Constructivist-based language learning mode emphasizes the student's subjective role, individual characteristics, authentic learning activities, and features of active learning. Student-centered teaching mode can help students learn English flexibly, effectively and efficiently.
\end{abstract}

Keywords-English language teaching; Constructivist; studentcentered teaching mode; individual cognitive constructivist

\section{INTRODUCTION}

Constructivist teachers encourage students to constantly assess how the activity is helping them gain understanding. By questioning themselves and their strategies, students in the constructivist classroom ideally become "expert learners." This gives them ever-broadening tools to keep learning. With a well-planned classroom environment, the students learn how to learn. The individual cognitive constructivists focus on the individual's reaction to an experience and to the process through which understandings are formed. Dewey and Piaget describe a similar process in which individuals find themselves in circumstances where they are uncomfortable and unable to easily explain the situation. New knowledge is then constructed as individuals restructure their knowledge in order to accommodate the new information.

The concept of constructivism has roots in classical antiquity, going back to Socrates's dialogues with his followers, in which he asked directed questions that led his students to realize for themselves the weaknesses in their thinking. The Socratic dialogue is still an important tool in the way constructivist educators assess their students' learning and plan new learning experiences. In this century, Jean Piaget[1] and John Dewey [2] developed theories of childhood development and education, what we now call Progressive
Education, that led to the evolution of constructivism. Piaget believed that humans learn through the construction of one logical structure after another. He also concluded that the logic of children and their modes of thinking are initially entirely different from those of adults. The implications of this theory and how he applied them have shaped the foundation for constructivist education. Dewey called for education to be grounded in real experience. Inquiry is a key part of constructivist learning. Morton examined a science teacher's use of and reflections on classroom talk in teaching a unit on genetics on a bilingual education programme. Constructivist, sociocultural and discursive psychological perspectives on conceptual change and classroom talk were reviewed[3]. Vygotsky presented a complex theory regarding the processes of thought and language. Speech was comprised of sets of sounds known as words. Without words, speech does not exist. Most importantly, without the presence of any meaning, speech has no relevance. Relevance is achieved through social interactions, and is changed based upon the context of a situation. If a child lacks certain levels of interaction, they will tend to digress in their ability to perform social speaking, and will focus their speech in egocentric speaking manner, where the child believes that their way of speaking is the way that all people converse[4]. Cui investigated the applications of modern educational technology in maritime English teaching from the perspective of constructivism[5]. Wu performed a study of oral English teaching and learning in vocational colleges from the perspective of constructivism [6]. Beck developed an exploratory study of teachers' beliefs regarding the implementation of constructivism in their classrooms [7]; Cooper discussed supporting high quality interaction and motivation in the classroom using ICT [8]. The aim of the paper is to discuss the teaching model of constructivism-based and offer some thoughts for reform in English teaching system.

\section{Two BASIC TEACHING MODES IN ENGLISH LANGUAGE TEACHING}

Classroom is recognized as social environment; often have a clear role relationship. The interaction of teacher-students and student-student in the classroom is essential since this is when learning takes place. This is more valid for language classrooms, where the teacher language serves a number of purposes such as organizing learning, providing meaningful input, controlling and eliciting learner output, amongst others. 
There are two kinds of teaching modes: teacher-centered mode of teaching and student-centered teaching mode. Both teaching modes contain the basic elements of teaching, teachers, and students, teaching content and teaching media. Table 1 lists the comparison between teacher-centered mode and student-centered mode.

TABLE I. COMPARISON BETWEEN TEACHER-CENTERED MODE AND STUDENT-CENTERED MODE

\begin{tabular}{|l|c|}
\hline \multicolumn{1}{|c|}{ teacher-centered mode } & \multicolumn{1}{c|}{ student-centered mode } \\
\hline $\begin{array}{l}\text { Curriculum begins with the parts of } \\
\text { the whole. Emphasizes basic skills. }\end{array}$ & $\begin{array}{c}\text { Curriculum emphasizes big concepts, } \\
\text { beginning with the whole and } \\
\text { expanding to include the parts. }\end{array}$ \\
\hline $\begin{array}{l}\text { Strict adherence to fixed curriculum } \\
\text { is highly valued. }\end{array}$ & $\begin{array}{c}\text { Pursuit of student questions and } \\
\text { interests is valued. }\end{array}$ \\
\hline $\begin{array}{l}\text { Materials are primarily textbooks and } \\
\text { workbooks. }\end{array}$ & $\begin{array}{l}\text { Materials include primary sources of } \\
\text { material and manipulative materials. }\end{array}$ \\
\hline Learning is based on repetition. & $\begin{array}{c}\text { Learning is interactive, building on } \\
\text { what the student already knows. }\end{array}$ \\
\hline $\begin{array}{l}\text { Teachers disseminate information to } \\
\text { students; students are recipients of } \\
\text { knowledge. }\end{array}$ & $\begin{array}{c}\text { Teachers have a dialogue with } \\
\text { students, helping students construct } \\
\text { their own knowledge. }\end{array}$ \\
\hline $\begin{array}{l}\text { Teacher's role is directive, rooted in } \\
\text { authority. }\end{array}$ & $\begin{array}{c}\text { Teacher's role is interactive, rooted in } \\
\text { negotiation. }\end{array}$ \\
\hline $\begin{array}{l}\text { Assessment is through testing, } \\
\text { correct answers. }\end{array}$ & $\begin{array}{l}\text { Assessment includes student works, } \\
\text { observations, and points of view, as } \\
\text { well as tests. Process is as important } \\
\text { as product. }\end{array}$ \\
\hline Knowledge is seen as inert. & $\begin{array}{c}\text { Knowledge is seen as dynamic, ever } \\
\text { changing with our experiences. }\end{array}$ \\
\hline Students work primarily alone. & \begin{tabular}{l} 
Students work primarily in groups. \\
\hline
\end{tabular} \\
\hline
\end{tabular}

Constructivist learning theory and teaching theory are based on the structure of the main theoretical basis for studentcentered teaching. Both teaching modes have their advantages and disadvantages. The outstanding merits of constructivist theory is conducive to the cultivation of creative thinking and innovation ability of creative talent; it requires teachers in the teaching process to give full play of the initiative and enthusiasm of the students in the learning process, to stimulate students' interest in learning, to create a relaxed harmonious learning atmosphere, so that students dare to speak, are willing to practice, to encourage students' progress timely bit by bit so that they foster self-confidence, a sense of achievement, to respect individual differences and special needs of students, to give the necessary guidance and assistance; to help students to explore their own learning methods to understand and master the law of the memory, to develop good studying habits, and develop independent learning ability. At the same time, the role of teachers is also made specific requests, the teacher's role is to organize the class inside and outside the various activities and guide students to learn English for their selection, doubts, and help groups to develop good study habits and culture of self-learning ability, so as to maintain a high learning enthusiasm.

\section{CONSTRUCTIVIST-BASED ENGLISH LANGUAGE TEACHING}

Constructivism is basically a theory about how people learn. It says that people construct their own understanding and knowledge of the world, through experiencing things and reflecting on those experiences. When we encounter something new, we have to reconcile it with our previous ideas and experience, maybe changing what we believe, or maybe discarding the new information as irrelevant. In any case, we are active creators of our own knowledge. To do this, we must ask questions, explore, and assess what we know.

Students learn more, and enjoy learning more when they are actively involved, rather than passive listeners. Education works best when it concentrates on thinking and understanding, rather than on rote memorization. Constructivism concentrates on learning how to think and understand. Constructivist learning is transferable. In constructivist classrooms, students create organizing principles that they can take with them to other learning settings. Constructivism gives students ownership of what they learn, since learning is based on students' questions and explorations, and often the students have a hand in designing the assessments as well.

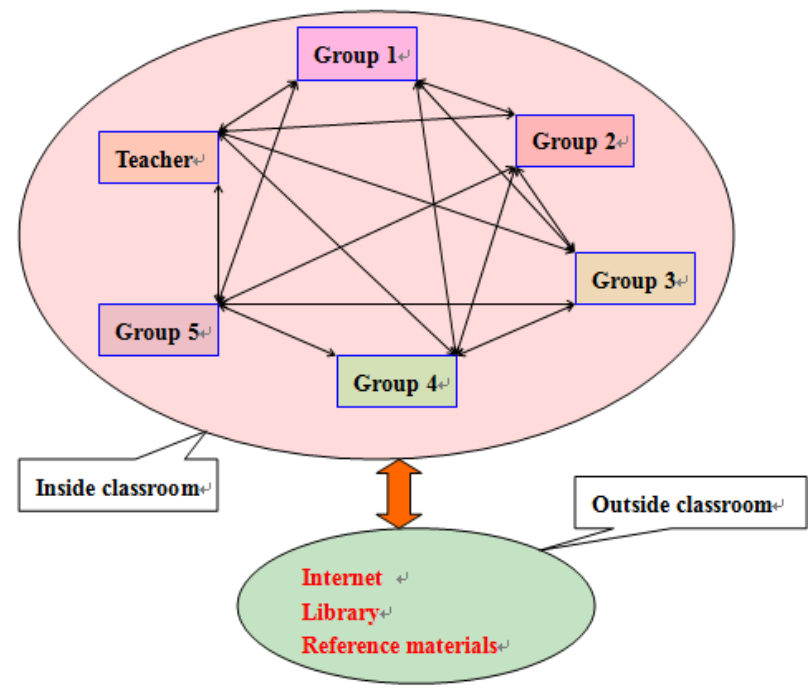

Fig. 1. constructivist-based English teaching

As shown in Fig. 1, the 30 students in one class are divided into 5 groups. The students in deferent groups can inquiry each other. The multiple intelligences and collaborative learning can be performed. The teaching approach is based on the student-centered constructivist paradigm. The general guidelines are in brief as followed: 1) Students are divided into a group of not more than six. 2) Every week each group is responsible for sharing its research finding regarding the content of each week lesson during the 3-hour session class. 3) Instructor executes as facilitator. 4) Use inquiry method that emphasizing the student-centre mode of instruction. 5) Students experience cooperative, reflective, and experiential learning, creative learning with critical thinking are among the focus.

The constructivist view of learning can point towards a number of different teaching practices. In the most general sense, it usually means encouraging students to use active techniques to create more knowledge and then to reflect on and talk about what they are doing and how their understanding is changing. The teacher makes sure she understands the students' preexisting conceptions, and guides 
the activity to address them and then build on them. Constructivist assessment engages the students' initiatives and personal investments in their journals, research reports, physical models, and artistic representations. Engaging the creative instincts develops students' abilities to express knowledge through a variety of ways. The students are also more likely to retain and transfer the new knowledge to real life. By grounding learning activities in an authentic, realworld context, constructivism stimulates and engages students. Students in constructivist classrooms learn to question things and to apply their natural curiosity to the world. Constructivism promotes social and communication skills by creating a classroom environment that emphasizes collaboration and exchange of ideas. Students must learn how to articulate their ideas clearly as well as to collaborate on tasks effectively by sharing in group projects. Students must therefore exchange ideas and so must learn to "negotiate" with others and to evaluate their contributions in a socially acceptable manner. This is essential to success in the real world, since they will always be exposed to a variety of experiences in which they will have to cooperate and navigate among the ideas of others.

The learning view of constructivism and the concept of students decide the new teaching idea of constructivism. This is reflected in the great changes in the role of the teacher and the students. Under the guidance of the teacher, the constructivism advocates taking learner as the center, taking into account the role of the learner's cognitive subject and the leading role of the teacher. Firstly, the role of teachers is changed from the traditional knowledge of the authority to the students' learning, and becomes a senior partner and partner of the students' learning. Teachers should not only provide students with a challenging problem, but also must realize that these questions have many answers, and encourage students to solve the problem of multiple perspectives. Teachers must create a good learning environment, so that students can start an independent inquiry and cooperative learning. Teachers must also provide students with meta-cognitive tools and psychological measurement tools, and train students' cognitive processing strategies and their own construction of knowledge and understanding of the psychological model. Secondly, teachers should actively promote students to construct knowledge and guide. Teachers should stimulate students' interest in learning, arouse and keep students' learning motivation. To help students construct the meaning of the current knowledge by creating a situation that meets the requirements of the teaching content and the connection between the old and new knowledge. Teachers should also organize collaborative learning as much as possible to discuss and exchange, and to guide the collaborative learning process, making it to the direction of the development of the significance of the construction. Teachers gradually develop the students' ability and habit of independent learning. The role of students is the active participant of the teaching activity and the active construction of knowledge. Constructivism requires students to form their own unique knowledge and understanding of the construction of the psychological model, take more independent learning and become the active construction of meaning, and be good at linking the current learning content with their existing knowledge and experience, and think about the relationship.

\section{Student-CEntered TeAching And LEARning Mode}

Student-centered learning puts students' interests first, acknowledging student voice as central to the learning experience. In a student-centered classroom, students choose what they will learn, how they will learn, and how they will assess their own learning. This is in contrast to traditional education, also dubbed "teacher-centered learning", which situates the teacher as the primarily "active" role while students take a more "passive", receptive role. In a teacher-centered classroom, teachers choose what the students will learn, how the students will learn, and how the students will be assessed on their learning. In contrast, student-centered learning requires students to be active, responsible participants in their own learning and with their own pace of learning.

Teaching mode is the stable structure of the teaching activity process under the guidance of certain educational theory, teaching theory and learning theory. The teaching activity process is usually referred to as the teaching process. The teaching activity process is usually referred to as the teaching process. As we all know, in the traditional teaching process, the teaching activity includes teachers, students, and teaching materials. In modern teaching, it is usually to use a variety of teaching media, so it should be added to the elements of Multimedia. These four elements in the teaching process is not isolated from each other, not related to the simple combination of each other, but the mutual connection, the formation of an organic whole. Since it is an organic whole, it must have a stable structure, which is formed by the four elements of the teaching process. The traditional teaching mode is Teacher-centered. The teachers use explanation, writing on the blackboard and a variety of media as the means and methods of teaching students to impart knowledge. Students passively accept teachers to impart knowledge. In this mode, the teacher is the active teaching them (knowledge, inculcating); students are passive recipients of external stimuli, instill knowledge object. Students are the passive recipients of external stimuli, the object of knowledge infusion. The teaching material is the content which the teacher teaches to the students; the teaching media is the method and the method which the teacher teaches the students.

Constructivist-based learning theory emphasizes the role of learners' cognitive subject actions. Instead of passive recipients of external stimuli, the students are the active construction of the subject. The evaluation for teachers' teaching effect depends on the students' learning effect. The success or failure of the teaching process is determined by if the students actively participate in the teaching process. Only learners have made clear the learning objectives, and actively learn to construct the knowledge. It is self-evident that the effective classroom teaching is the process of exerting the students' active status and guiding students' active learning. Only the inherent learning needs of the students are changed into a personal behavior, students can really develop their potential, construction of knowledge. In order to emphasize students as the subject, students' autonomous learning English can be promoted. It is very important to stimulate students' intrinsic 
motivation to learn, to teach students learning and inductive method of new English knowledge rather than a single point of language, to guide students to consciously collaboration and positive communication, to remind students in the English learning process in continuous self monitoring and adjustment.

Student-centered teaching and learning mode can prompt students to formulate their own questions, allow multiple interpretations and expressions of learning, and encourage group work and the use of peers as resources. Students are not blank slates upon which knowledge is etched. They come to learning situations with already formulated knowledge, ideas, and understandings. This previous knowledge is the raw material for the new knowledge they will create.

Student-centered teaching methods shift the focus of activity from the teacher to the learners. These methods include active learning, in the student to solve the question, answer questions, formulate their own problems, discussion, explanation, debate, or brainstorming in the classroom; cooperative learning, under the condition of student work to ensure positive interdependence relationship and personal responsibility and project team; the inductive teaching and learning, in students is of course material is put forward for the first time the challenges and learning background, to meet the challenges. Inductive approach consists of inquiry based learning, case teaching, problem based learning, project based learning, discovery learning, and timely teaching. Student centered approach has been shown to be superior to the traditional teacher centered teaching method, and concludes that the results are applicable to assess whether the results are short-term, long-term retention, or depth understanding of curriculum materials, the ability to collect critical thinking and creative problem-solving skills, to form positive attitudes toward the subject, or the level of knowledge or skills.

The theory of constructivism is clear to students as the center. Teachers are the guides and the monitor. To make full use of the learning process, such as situation, cooperation, conversation and meaning construction, we can achieve the purpose of teaching the students to realize the significance of the current knowledge. We should abandon the traditional teaching in order to teach knowledge as the center of the topdown teaching mode. Students should not be the container of knowledge. The teaching design should take the study as the center, should set up the teaching idea from the bottom up. In this process, students should have to complete the tasks required to complete the task, as well as all levels of knowledge and skills required to accomplish the tasks at all levels. The learners are the construction of their own knowledge. Their knowledge construction activities directly determine the effect of teaching, so they are the masters of the learning process. The core role of the teacher is not to impart knowledge to students, but rather how to lead and promote the students' knowledge construction activities. Every teaching decision of the teacher should be based on the students' understanding, thinking, feeling and activity. Teaching should start from the students' experience, and achieve the construction of new experience.

\section{CONCLUSIONS}

Teacher talk plays an important role in language teaching. Teachers use the target language to meet many uses, including the modeling language, to seek information, provide opportunities for input and output, as well as the lessons learned, and the organization of the learning environment for the management of natural interactions. With the emergence of social constructivist learning method, the role of language in the learning process has been the concern of people.

Constructivist classroom makes teacher as a guide rather than an authority of a subject, while students are active researchers and the knowledge of the discovery. Traditional classroom teaching takes the teacher as the sole authority, depending on the text, through the repetition of teaching, through the examination, the examination knowledge. Constructivist classroom uses of the main resources to teach, interactive learn, group work and the student-led pursuits.

\section{REFERENCES}

[1] J. Piaget and B. Inhelder, "The Psychology of the child," New York: Basic Books, Inc., 1969.

[2] J.Dewey, "Democracy and Education". New York: MacMillan, 1959.

[3] T. Morton, "Classroom talk, conceptual change and teacher reflection in bilingual science teaching," Teaching and Teacher Education, vol. 28 , 2012, pp.101-110.

[4] L.S. Vygotsky, "Mind in society: The development of higher psychological processes", Cambridge: MA, Harvard University Press, 1978.

[5] Z. Cui, "On the Applications of Modern Educational Technology in Maritime English Teaching from the Perspective of Constructivism," English Language Teaching, vol. 3, 2010, pp. 244-248.

[6] Y. Wu, "A study of oral English teaching and learning in vocational colleges from the perspective of constructivism," Overseas English, vol. 3, 2014, pp. 64-65.

[7] J. Beck, C. H.,Czerniak, \& A. Lumpe, "An exploratory study of teachers' beliefs regarding the implementation of constructivism in their classrooms," Journal of Science Teacher Education, vol. 11, 2000, pp. 323-343.

[8] B. Cooper, \& P. Brna, "Supporting high quality interaction and motivation in the classroom using ICT: The social and emotional learning and engagement in the NIMIS project," Education, Communication and Information, vol. 2, 2002, pp.113-138. 